\title{
Detection of high prevalence of Plasmodium falciparum histidine-rich protein $2 / 3$ gene deletions in Assosa zone, Ethiopia: implication for malaria diagnosis
}

Gezahegn Solomon Alemayehu ${ }^{1 *}$, Kayla Blackburn², Karen Lopez ${ }^{2}$, Cheikh Cambel Dieng $^{3}$, Eugenia Lo ${ }^{3}$, Daniel Janies ${ }^{2}$ and Lemu Golassa'

\begin{abstract}
Background: Rapid diagnostic tests (RDTs) targeting histidine rich protein 2(HRP2) are widely used for diagnosis of Plasmodium falciparum infections. Besides PfHRP2, the PfHRP3 antigen contributes to the detection of $P$. falciparum infections in PfHRP2 RDTs. However, the performance HRP2-based RDT is affected by pfhrp 2/3 gene deletions resulting in false-negative test results. The objective of this study was to determine the presence and prevalence of pfhrp2/3 gene deletions including the respective flanking regions among symptomatic patients in Assosa zone, Northwest Ethiopia.

Methods: A health-facility based cross-sectional study was conducted in febrile patients seeking a malaria diagnosis in 2018. Blood samples were collected by finger-prick for microscopic examination of blood smears, malaria RDT, and molecular analysis using dried blood spots (DBS) prepared on Whatman filter paper. A total of 218 P. falciparum positive samples confirmed by quantitative PCR were included for molecular assay of pfhrp 2/3 target gene.

Results: Of 218 P. falciparum positive samples, exon 2 deletions were observed in 17.9\% of pfhrp2 gene and in 9.2\% of pfhrp3 gene. A high proportion of deletions in short segments of pfhrp2 exon1-2 (50\%) was also detected while the deletions of the pfhrp3 exon1-2 gene were $4.1 \%$. The deletions were extended to the downstream and upstream of the flanking regions in pfhrp2/3 gene (above 30\%). Of eighty-six PfHRP2 RDT negative samples, thirty-six lacked pfhrp2 exon 2. Five PfHRP2 RDT negative samples had double deletions in pfhrp2 exon 2 and pfhrp3 exon2. Of these double deletions, only two of the samples with a parasite density above 2000 parasite/ $\mu$ l were positive by the microscopy. Three samples with intact pfhrp3 exon2 in the pfhrp2 exon2 deleted parasite isolates were found to be positive by PfHRP2 RDT and microscopy with a parasite density above 10,000/ $\mu$ l.

Conclusion: This study confirms the presence of deletions of pfhrp $2 / 3$ gene including the flanking regions. Pfhrp $2 / 3$ gene deletions results in false-negative results undoubtedly affect the current malaria control and elimination effort in the country. However, further countrywide investigations are required to determine the magnitude of pfhrp2/3 gene deletions and its consequences on routine malaria diagnosis.
\end{abstract}

Keywords: Plasmodium falciparum, Pfhrp2/3 gene deletion, PfHRP2 RDT, Microscopy, PCR, Assosa, Ethiopia

*Correspondence: gezasolo2020@gmail.com

${ }^{1}$ Addis Ababa University, Aklilu Lemma Institute of Pathobiology, Addis Ababa, Ethiopia

Full list of author information is available at the end of the article

\section{Background}

Despite significant progress made in the last decade towards malaria control and elimination in most malariaendemic countries in the world, malaria is still a major

(c) The Author(s) 2021. This article is licensed under a Creative Commons Attribution 4.0 International License, which permits use, sharing, adaptation, distribution and reproduction in any medium or format, as long as you give appropriate credit to the original author(s) and the source, provide a link to the Creative Commons licence, and indicate if changes were made. The images or other third party material in this article are included in the article's Creative Commons licence, unless indicated otherwise in a credit line to the material. If material is not included in the article's Creative Commons licence and your intended use is not permitted by statutory regulation or exceeds the permitted use, you will need to obtain permission directly from the copyright holder. To view a copy of this licence, visit http://creativeco mmons.org/licenses/by/4.0/. The Creative Commons Public Domain Dedication waiver (http://creativecommons.org/publicdomain/ zero/1.0/) applies to the data made available in this article, unless otherwise stated in a credit line to the data. 
public health problem [1]. Plasmodium falciparum and Plasmodium vivax co-exist in Ethiopia [2]. Plasmodium falciparum is responsible for most of the malaria-associated deaths in malaria endemic countries. Accurate malaria diagnostic tools and prompt treatment play an important role in reducing morbidity and mortality of malaria [3].

To date, the approach to malaria diagnosis depends on the specific requirements of the malaria program and the dynamics of malaria transmission. Microscopy and rapid diagnostic tests (RDTs) are the most common front-line diagnostic tools in clinical settings. Molecular diagnostic methods are recently used in countries with low-transmission setting and/or approaching malaria elimination phase [4].

Malaria RDTs targeting histidine-rich protein-2 (HRP2) and lactate dehydrogenase (LDH) are commonly used for diagnosis of $P$. falciparum and non-falciparum malaria parasites, respectively. In Ethiopia, where $P$. falciparum predominates, PfHRP2 RDT is widely used [5]. However, a number of factors would affect the performance of PfHRP2 RDT. Among others, the lack of HRP2 antigen production in $P$. falciparum parasites due a deletion of parts or all of the pfhrp2 gene [6], affects the sensitivity and specificity of HRP2 RDTs. Besides, PfHRP2, the PfHRP3 antigen produced by P. falciparum has been shown to share high homology with PfHRP2 [7]. This PfHRP3 antigen may contribute to the detection of $P$. falciparum infections in PfHRP2 RDTs, but the performance of these RDTs could also be affected if there is a deletion of the pfhrp3 gene in P. falciparum [8].

Interestingly, partial or entire deletion of pfhrp 2 and pfhrp3 genes in P. falciparum populations could result in false negative RDT-based diagnosis of malaria [6], which would delay timely prescription of anti-malarial drugs and allow the rapid spread of these genotypes from untreated patients into the communities. Therefore, $P$. falciparum populations containing these variants of the pfhrp 2 and pfhrp 3 genes would be selected and would remain a major threat to existing malaria case management and control efforts [9].

In recent years, deletion of $p f h r p 2$ and/or $p f h r p 3$ genes have been reported in different geographical regions including the Peruvian Amazon Basin [10], Brazil [11], India [12], and Senegal [13]. The effect of pfhrp 2 and pfhrp3 gene deletion on the performance of PfHRP2RDTs have also been evaluated in a few East African neighbouring countries of Ethiopa, such as Eritrea [14], Sudan [15], and Kenya [16]. Therefore, it is very important to explore the presence and prevalence of $p f h r p 2 / 3$ gene deletions in the Ethiopian P. falciparum populations. Moreover, there are no reports of $p f h r p 2 / 3$ genes deletions in Assosa zone in Northwest Ethiopia. Thus, objective of this study was to assess the presence and prevalence of $p f h r p 2 / 3$ genes deletion as well as the respective flanking regions among $P$. falciparum isolates in this area.

\section{Methods \\ Study area}

A cross-sectional study was conducted in clinical setting during low and high transmission seasons at four selected health facilities: Assosa, Bambasi, Kurmuk and Sherkole Health Centres in Assosa Zone, BenishangulGumuz Regional State, Northwest Ethiopia from November to December 2018. The study area was selected using a simple random sampling technique among eight districts in the Assosa zone. Most of the district has a high intensity of transmission according to the annual parasite incidence report [2]. Majority of the population of the districts are permanent residents and depends mainly on agricultural and mining work. The study area is located on the northwestern border of Ethiopia where there is a local cross-border market between the people of Sudan and Ethiopia. In line with this, there is import and export of the malaria parasite between the two countries. Recently, there is a confirmed report of the pfhrp $2 / 3$ gene deletion in Sudan [15]. Thus, this study was design to assess the presence and magnitude of the pfhrp $2 / 3$ gene deletion on the northwestern border of Ethiopia. The geographic locations of the study sites was taken by handheld GPS (Garmin GPS 73, United State) and the map was generated using ArcGIS version 10.0 software (Fig. 1).

\section{Blood sample collection}

Demographic data were collected at the time of enrollment from clinically suspected malaria patients. Simultaneously, in a single finger-prick, capillary blood sample was collected from each study participant for thin and thick blood smear preparation for microscopy, and Malaria RDT. Dried blood spots (DBSs) were spotted on Whatman $^{\mathrm{TM}}$ FTA $^{\mathrm{TM}}$ filter paper (GE Healthcare, Piscataway, NJ, USA) for molecular assay.

\section{Detection of $P$. falciparum by microscopy and malaria RDT}

Thin and thick blood smears were prepared and stained with Giemsa stain working solution diluted in $10 \%$ buffer for microcopy detection of Plasmodium parasites. Briefly, Giemsa working stain solution prepared by a stock volume of Giemsa with nine volumes of buffered water with $\mathrm{pH}$ 7.2. Thin blood smear fixed with methanol solution and staining with Giemsa working stain for 10 min on the staining rack. Thin smears were used to identify Plasmodium parasites species while the thick smears were examined to detect and measure the density of the parasite against 200 white blood cells (WBC), assuming mean 


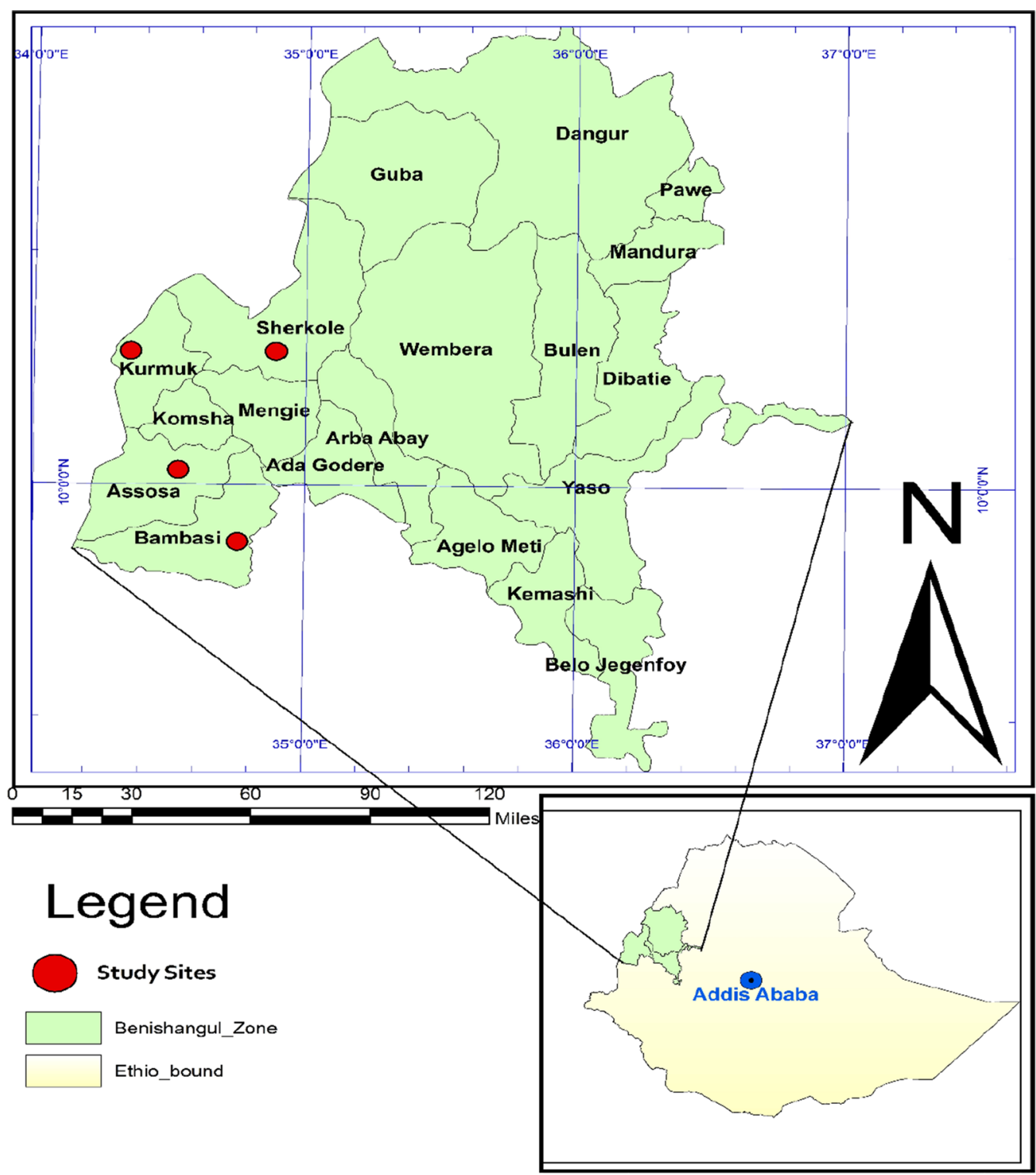

Fig. 1 The map showing the study area in Assosa zone. The map generated using ArcGIS version 10.0 software

WBC count was $8000 / \mu \mathrm{L}$, as per WHO recommendations [17]. The Care Start ${ }^{\mathrm{TM}}$ malaria RDT (Pf/PV (HRP2/ PLDH, RMVM-02591) was performed and interpreted based on the manufacturer's instructions in the package insert.

\section{DNA extraction and quantitative PCR}

Genomic DNA was extracted from blood DBS using Chelex-Saponin method as described previously [18]. Plasmodium falciparum identification were confirmed by SYBR green based quantitative PCR (qPCR) assay by targeting the $18 \mathrm{~S}$ rRNA gene using species-specific primers as described elsewhere [19]. Absolute quantification approach was used to quantify unknown samples by qPCR. Serially diluted known quantity of parasite DNA amplified to generate a standard curve. Then, quantifications were performed by comparing Ct-value for unknown samples against this a standard curve.

\section{Amplification of pfhrp2 and pfhrp3 genes}

Of the 499 malaria suspected individuals selected for molecular analysis, a total of 218 qPCR confirmed $P$. falciparum positive samples with $\mathrm{Ct}$-value $<37$ were included for $p f h r p 2 / 3$ molecular analysis to minimize 
false negative finding of $p f h r p 2 / 3$ associated with low density infection in this study (Additional file 1). This study protocol included both the positive and negative samples by microscopy and PfHRP2 RDT to reduce underestimation of $p f h r p 2 / 3$ gene deletion due to submicroscopic samples.

After confirmation of $P$. falciparum positive samples by $\mathrm{qPCR}, p f h r p 2$ and $p f h r p 3$ gene analysis was performed by amplification of two amino acids coding segments (exon2 and exon1-2). The short segment, exon1-2, spans the end of exon1 to the start of exon2. The longest segment, exon 2, consists of the entire exon 2 which is the main amino acid coding region of pfhrp 2 and $p f h r p 3$ genes. PCR amplifications were performed on upstream (PF3D7_0831900 (MAL7P1_230) and downstream (PF3D7_0831700 (MAL7P1_228) flanking region of $p f h r p 2$ gene. Likewise, PCR amplifications were also performed on upstream PF3D7_1372100 (MAL13P1_475) and downstream (PF3D7_1372400 (MAL13P1_485) flanking regions of $p f h r p 3$ gene. The study flow chart for molecular analysis of $p f h r p 2$ and $p f h r p 3$ is indicated in Additional file 1.

PCR amplification of pfhrp2, pfhrp3 genes and their respective flanking regions were carried out in the total reaction mixture of $25 \mu$ l using $2 \mathrm{X}$ Go Taq hot start green master mix (Integrated DNA Technologies, Inc, Coraville, USA). 0.4 $\mu \mathrm{M}$ each of forward and reverse primer, $3 \mu \mathrm{l}$ of template DNA for each pfhrp 2 exon2, pfhrp 3 exon 2 and pfhrp 3 exon12, $2 \mu \mathrm{l}$ of template DNA for each pfhrp2 exon1-2, MAL7P1_230 and MAL13P1_475, $1 \mu \mathrm{l}$ of template DNA for each MAL13P1_485 and MAL7P1_228 were used based on PCR conditions and primer sequences as described previously $[9,20,21]$. As a positive control, 3D7 (MRA-102G) was used for PCR amplification of pfhrp2, pfhrp 3 and their respective flanking genes. Likewise, DNA of laboratory strains Dd2 (MRA-150G) and HB3 (MRA155G) were used as negative control for the PCR amplifications of $p f h r p 2$ and $p f h r p 3$ including their flanking genes, respectively [10]. All pfhrp $2 / 3$ PCR negative samples were repeated to confirm the absence of the target gene ( $p$ fhrp $2 / 3$ exon 2 and exon $1-2)$ including flanking regions.

The amplified fragments of $p f h r p 2, p f h r p 3$ and their flanking genes were separated by electrophoresis on a $2 \%$ agarose gel by staining with SYBR safe in a Tris Borate EDTA (TBE) buffer. The DNA bands were visualized in a UV transilluminator and the expected amplicons size compared to $1 \mathrm{~kb}$ DNA ladder. Primer sequences, PCR conditions and expected amplicon size of $p f h r p 2 / 3$ genes are indicated in Additional file 2.

\section{Data analysis}

The proportion of $p f h r p 2 / 3$ gene deletions were analysed using Statistical Package for Social Sciences (SPSS) version 20. $P$ value $<0.05$ were considered as significant.

\section{Results}

\section{qPCR, microscopy and PfHRP2 RDTs}

A total of 218 P. falciparum positive samples by qPCR were included based on inclusion criteria for molecular analysis of $p f h r p 2$, pfhrp 3 gene and their flanking gene. Of the study participants positive for P. falciparum by qPCR, $56 \%(122 / 218)$ and $62.8 \%(137 / 218)$ of the positive cases were female and in the youngest age group (5-24 years), respectively. PfHRP2 RDT and microscopy detected approximately $60 \%$ of infections that were detectable by qPCR. There is statistical difference in positivity rate of PfHRP2 RDTs with respect to gender $(P=0.028)$ and age group $(P=0.05)$ (Table 1$)$.

\section{Deletions in pfhrp2 and pfhrp3 genes}

Among the $218 P$. falciparum positive isolates, exon 2 deletions were observed in $17.9 \%$ (39/218) of $p f h r p 2$ gene and in 9.2\% (20/218) of pfhrp3 gene. Likewise, deletions of the pfhrp2 exon1-2 gene exhibited in 50\% (109/218) of the isolates while deletions of the pfhrp3 exon12 gene were $4.1 \%(9 / 218)$. The deletions extended to

Table 1 Demographic data of $P$. falciparum positive study participants by laboratory test

\begin{tabular}{llll}
\hline Variables & \multicolumn{2}{l}{ Number of positive samples by Laboratory test } \\
\cline { 2 - 4 } & qPCR & Microscopy & PfHRP2 RDT \\
& No (\%) & No (\%) & No (\%) \\
\hline Sex & & & \\
Male & $96(44.0)$ & $62(64.6)$ & $66(68.8)$ \\
Female & $122(56 \%)$ & $69(56.6)$ & $66(54.1)$ \\
P-value* & & $P=0.230$ & $P=0.028$ \\
Age groups & & & \\
5-14 & $56(25.7)$ & $42(75.0)$ & $43(76.8)$ \\
15-24 & $81(37.2)$ & $50(61.7)$ & $47(58.0)$ \\
25-34 & $47(21.6)$ & $23(48.9)$ & $23(48.9)$ \\
35-44 & $19(8.7)$ & $9(47.4)$ & $11(57.9)$ \\
45-57 & $15(6.9)$ & $7(46.7)$ & $8(53.3)$ \\
Pvalue & & $P=0.038$ & $P=0.051$ \\
Study site & & & $63(67.0)$ \\
Sherkole & $94(43.1)$ & $63(67.0)$ & $46(69.7)$ \\
Bambasi & $66(30.3)$ & $43(65.2)$ & $19(45.2)$ \\
Kurmuk & $42(19.3)$ & $20(47.6)$ & $4(25.0)$ \\
Assosa & $16(2.8)$ & $5(31.3)$ & $P=0.001$ \\
$P$ value & & $P=0.013$ & \\
\hline
\end{tabular}

No Number, \% percent, Pf Pos P. falciparum Positive

* Statistically significant at $p$-value less than 0.05 


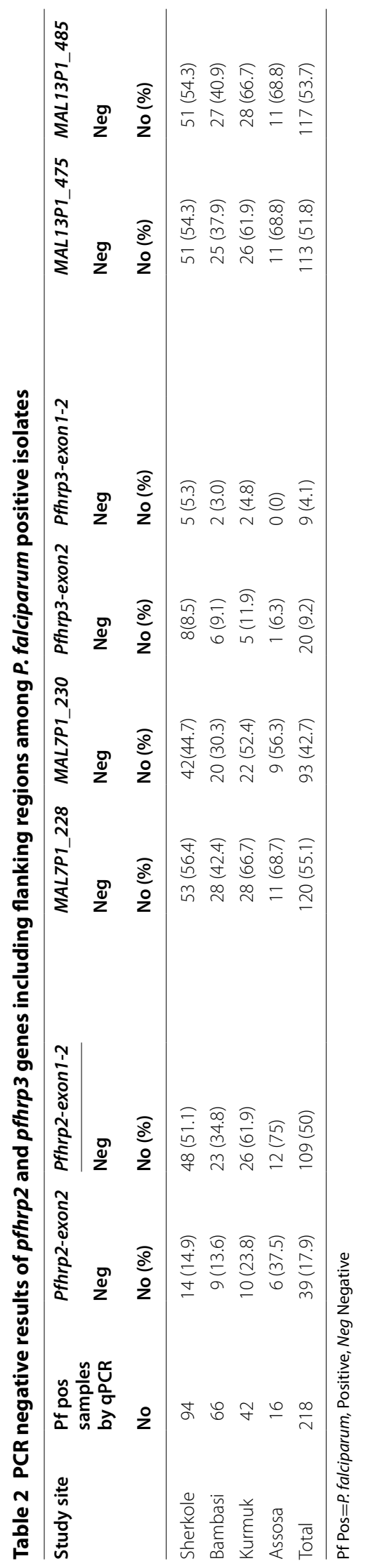


upstream and downstream of the flanking genes of both pfhrp2 (MAL7P1_230 and MAL7P1_228) and pfhrp3 (MAL13P1.475 and MAL13P1.485) accounting for $40 \%$ of the deletions. The deletion pattern of $P f h r p 2 / 3$ and its flanking region was varied in different isolates of $P$. falciparum. Of the 218 P. falciparum isolates, $37.2 \%$ of the isolates did not have deletions in the $p f h r p 2 / 3$ gene, including its flanking regions (Additional file 3 ).

The pattern of deletions in $p f h r p 2 / 3$ genes and their flanking regions varies according to the study sites. The high proportion of deletions of the pfhrp 2 exon 2 gene were observed in $37.5 \%(6 / 16)$ of the isolates collected at the Assosa health centre (Table 2).

\section{Pfhrp2/3 genes deletions by transmission seasons}

A comparable $p f h r p 2 / 3$ genes deletions were observed in both high and low transmission seasons. The frequency of pfhrp 2 exon 2 deletion was 19.9\% (30/167) in high transmission season and $17.7 \%(9 / 51)$ in the low transmission season. The frequency of pfhrp 3 exon 2 deletion was $8.4 \%$ $(14 / 167)$ and $11.8 \%(6 / 51)$ in high and low transmission seasons, respectively. The extent of deletions of $p$ fhrp $2 / 3$ exon 2 varied by the study site. High proportion deletion of pfhrp2 exon2 (46.2\%) was observed in the Assosa district during the high transmission season followed by $28.6 \%$ of pfhrp 2 exon2 deletion in Bambasi district during low transmission season (Fig. 2).

\section{PfHRP2 RDT and microscopy compared to PCR results of pfhrp2 and pfhrp3}

Of eighty-six PfHRP2 RDT negative samples, 41.9\% (36/86) samples lacked pfhrp2 exon 2 as compared to $10.5 \%(9 / 86)$ deletions observed in pfhrp3 exon 2 (Table 3). Of thirty-six pfhrp 2 exon 2 PCR negative samples, thirty-three samples were submicroscopic unlike the three samples with the parasite densities above 1000 $/ \mu \mathrm{l}$ (Additional file 4). A total of five PCR double negative samples for pfhrp 2 exon 2 and pfhrp 3 exon 2 gene were also PfHRP2 RDT negative (Fig. 3). Among those five PCR double negative results of pfhrp 2 exon 2 and pfhrp3 exon2 gene, two PfHRP2 RDT negative samples with parasite density above 2000 parasite/ $\mu \mathrm{l}$ were microscopy positive while three of them were submicroscopic (Table 4). On the other hand, three pfhrp3 exon2 PCR positive isolates lacked the $p f h r p 2$ exon2 gene. These three samples had a parasite density greater than 10,000 / $\mu \mathrm{l}$ and were positive both by PfHRP2 RDT and microscopy in the absence of the pfhrp 2 gene, suggesting the contribution of intact $p f h r p 3$ exon 2 to reduce false negative PfHRP2 RDT despite a deletion in the $p f h r p 2$ gene (Additional file 5).

Regarding exon1-2 of $p f h r p 2 / 3$, a high proportion of negative samples of PfHRP2 RDT lacked exon1-2 of pfhrp2 $(93 \%, 80 / 86)$ compared to exon 1-2 of pfhrp3 $(8.1 \%, 7 / 86)$. Out of eighty pfhrp 2 exon1-2 PCR negative samples, only five samples were tested positive for microscopy (Table 3). Furthermore, among eight PCR double negative results for pfhrp2 exon1-2 / pfhrp3 exon1-2, seven samples were negative for both PfHRP2 RDT and microscopy (Fig. 3).

\section{PfHRP2 RDT results against PCR results of $p$ fhrp2/3 flanking regions}

Out of eighty-six PfHRP2 RDT negative samples, more than $80 \%$ of the samples lacked MAL7P1_230, MAL13P1_475, MAL7P1_228 and MAL13P1_485 in both the upstream and downstream pfhrp $2 / 3$ flanking region (Additional file 6). Out of eight-six double deletions of MAL7P1_230 and MAL13P1.475, sixty-six negative samples were found by PfHRP2 RDT and sixty-five negative samples by microscopy. Of one hundred twelve double deletions of MAL7P1_228 and MAL13P1.485, a total of eighty-one samples by PfHRP2 RDT and eightytwo samples by microscopy were negative (Fig. 3).

\section{Discussion}

This study confirmed the presence of a considerable number of $p f h r p 2 / 3$ gene deletions in $P$. falciparum clinical isolates in the Assosa zone, Northwest Ethiopia. Partial deletions of $p f h r p 2$, pfhrp3, and the flanking genes were observed in the majority of the parasite populations while complete deletion of $p f h r p 2 / 3$ gene occurred only in two of $P$. falciparum clinical isolates. On the other hand, $37.2 \%(81 / 218)$ of the clinical isolates did not have deletion in exon 2 and exon 1-2 of $p f h r p 2 / 3$ region including the flanking regions.

Of 218 positive samples for $P$. falciparum, microscopy and RDT were able to detect almost $60 \%$ of the infections detected by qPCR. If these large number of false negatives individual remain undetected and untreated, they could likely serve as malaria reservoirs and accelerate the onward transmission of malaria in the community[22]. High proportion of PfHRP2 RDT false-negative results in this study is suggested to be due to the deletion of pfhrp $2 / 3$ gene in the P. falciparum populations.

The prevalence of $p f h r p 2$ exon2 deletion in this study $(17.9 \% ; 39 / 218)$ varied with the findings reported by previous studies such as comparable results in Kenya [16], lower results in Ethiopia [23], Mozambique [24], China [25], and higher than the current study in Ethiopia [26], Eritera [14] and Sudan [15]. Likewise, the pfhrp3 exon2 deletion $(9.2 \%$; 20/218) in this study was higher than study in Kenya [16], but lower than deletions reported from Ethiopia [26], Eritera [14], Ghana [27], and Honduras [21]. Regarding transmission season, a comparable number of $p f h r p 2 / 3$ genes deletions were observed 


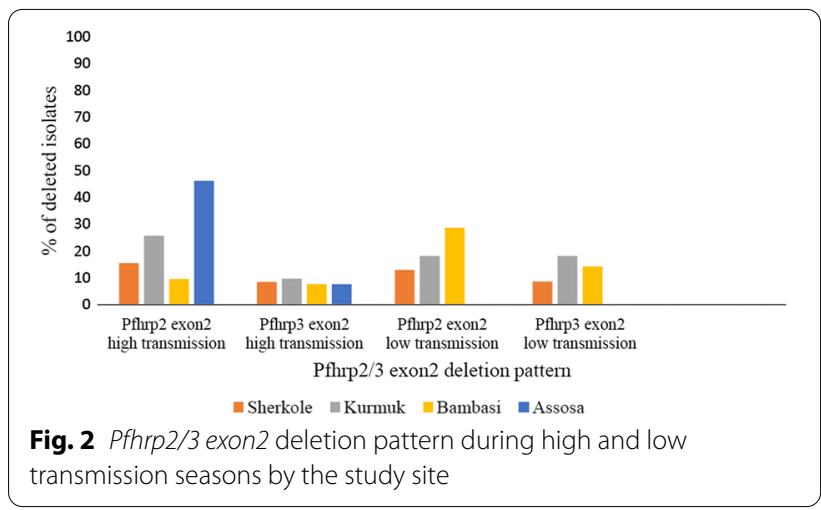

in both high and low transmission seasons in this study area. This finding contrast with other studies in Rwanda [28] and Zanzibar [29]. The possible explanation for these differences might be due to variation in transmission intensity $[28,30]$, host immunogenic response [31, 32], drug used [33], geographical locations [8, 34], sample size, and laboratory methods [35-37] used to analyse pfhrp $2 / 3$ genes deletions.

Out of a total of 39.5\% (86/218) PfHRP2 RDT negative samples in this study, a high proportion of PCR confirmed deletions were observed in pfhrp $2 / 3$ exon 2 and exon 1-2, and upstream and downstream flanking regions of $p f h r p 2 / 3$ compared to WHO pfhrp $2 / 3$ deletion threshold level [38]. Approximately forty-two percent of (36/86) PfHRP2 RDT negative samples lacked exon 2 of pfhrp2, the main amino acid coding region of the $p f h r p 2$ gene. Of these PCR negative Pfhrp2 exon 2 samples, only three of the samples with a parasite density above $1000 / \mu \mathrm{l}$ were microscopic positive while the rest were submicroscopic. Moreover, high prevalence of deletion was detected in short segmented of pfhrp2 exon1-2(50\%) and pfhrp3 exon1-2(4.1\%). High proportion of deletions (>30\%) was also extended to the downstream and upstream of the flanking regions in $p f h r p 2 / 3$ gene. The complete and partial $p f h r p 2 / 3$ genes deletions observed in this study would undoubtedly impact the diagnostic performance of PfHRP2 RDTs.

According to the WHO protocol, a deletion of the pfhrp $2 / 3$ gene in a certain region will be suspected if there is an increase in discordant reports between routine diagnostic tools, such as microscopy positive and PfHRP2 RDT negative [9]. The protocol for this study reiterates that submicroscopic infections should not be overlooked when it comes to pfhrp $2 / 3$ gene deletions. Therefore, positive and negative microscopic results were included in this study to reduce underestimation of the true prevalence of $p f h r p 2 / 3$ gene deletion due to
Table 3 PfHRP2 RDT and Microscopy results against PCR results of pfhrp2 and pfhrp3

\begin{tabular}{|c|c|c|c|c|}
\hline \multirow[t]{2}{*}{ PCR results } & \multicolumn{2}{|l|}{ PfHRP2 RDTs } & \multicolumn{2}{|l|}{ Microscopy } \\
\hline & No positive & No negative & No positive & No negative \\
\hline \multicolumn{5}{|c|}{ Pfhrp2 exon 2} \\
\hline Positive & 129 & 50 & 125 & 54 \\
\hline Negative & 3 & 36 & 6 & 33 \\
\hline \multicolumn{5}{|c|}{ Pfhrp3 exon 2} \\
\hline Positive & 121 & 77 & 117 & 81 \\
\hline Negative & 11 & 9 & 14 & 6 \\
\hline \multicolumn{5}{|c|}{ Pfhrp2 exon 1-2 } \\
\hline Positive & 103 & 6 & 104 & 5 \\
\hline Negative & 29 & 80 & 27 & 82 \\
\hline \multicolumn{5}{|c|}{ Pfhrp3 exon 1-2 } \\
\hline \multicolumn{2}{|c|}{ Positive 130} & 79 & 129 & 80 \\
\hline Negative & 2 & 7 & 2 & 7 \\
\hline
\end{tabular}

submicroscopic infection. As a result, thirty-three samples with the pfhrp 2 deletion gene were found to be submicroscopic in this study and included only those samples with a $\mathrm{Ct}$ value below 37 using qPCR (and hence had $>9$ parasite density/ $\mu$ l) to minimize the risk of finding false deletion results associated with a single copy of the target gene (Pfhrp2) and low-density infection. P. falciparum positive clinical isolates with $p$ fhrp $2 / 3$ gene deletion may selectively increase if there is no continuous monitoring associated with submicroscopic infections and PfHRP2 RDT negative results. Those parasites with submicroscopic parasite densities with $p$ fhrp $2 / 3$ gene deletions could be potentially infectious to mosquitoes and contribute to ongoing malaria transmission which could in turn challenge malaria control and prevention.

In this study, 58.1\% (50/86) false negative PfHRP2 RDT results were found to be $p f h r p 2$ exon 2 positive by PCR. The likely cause of these false negative PfHRP2 RDT results could be due to low levels of parasitaemia that could be below the detection threshold of PfHRP2 RDT in those submicroscopic infections and absence of PfHRP2 antigen due to host immune response in the high transmission areas [39].

All PCR double negative samples in $p f h r p 2 / 3$ genes and their flanking regions were PfHRP2 RDT negatives in this study. The number of PCR double negative samples of pfhrp 2 exon 2 and pfhrp 3 exon 2 were low compared to previous studies in Peru [10] and Ghana [27]. In the reported study, discordant results between PfHRP2 RDT and microscopy were observed in five PCR double negative samples of $p f h r p 2$ exon 2 and pfhrp 3 exon 2. Two 


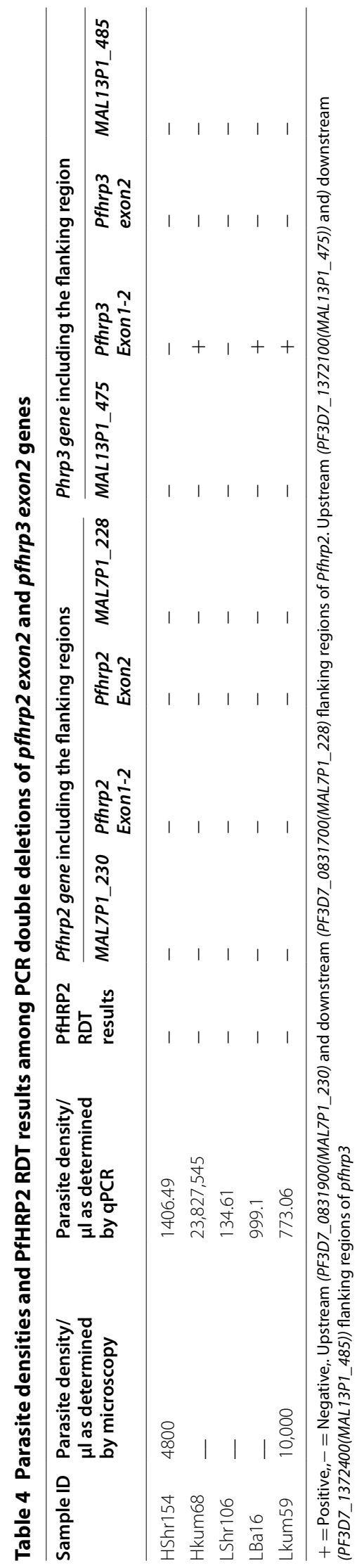




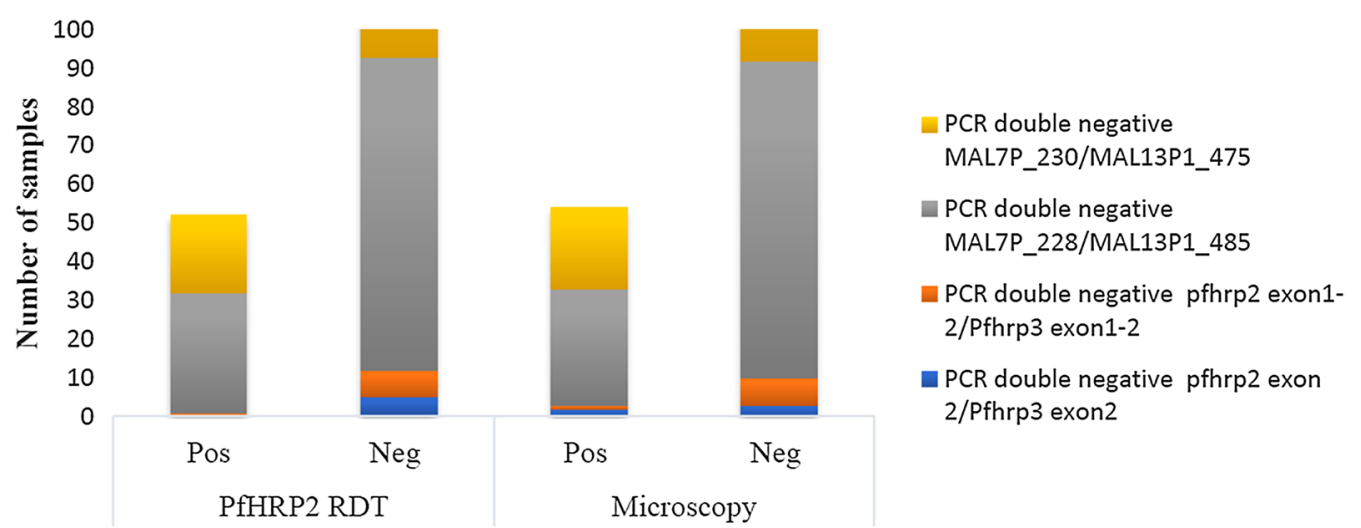

Fig. 3 PfHRP2 RDT and Microscopy results associated with PCR double negative results of $P f h r p 2 / 3$ genes including flanking region among $P$. falciparum positive isolate. Note: Upstream (MAL7P1_230) and downstream (MAL7P1_228) flanking regions of Pfhrp2. Upstream (MAL13P1_475) and downstream (MAL13P1_485) flanking regions of pfhrp3

PfHRP2 RDT negative samples were microscopic-positive with a parasite density above 2000 parasite/ $\mu$ l while the remaining three samples were submicroscopic. The presence of double deletions of $p f h r p 2 / 3$ genes in this study would indicate the potential challenge of PfHRP2 RDT based malaria diagnosis in the study area.

The contribution of intact $p f h r p 3$ gene to PfHRP2 RDT positive results is noted in the study under report. Even though only three pfhrp 3 exon 2 PCR positive samples were lacking pfhrp2 exon2, these three samples were confirmed positive by PCR and microscopy with parasite density above $10,000 / \mu \mathrm{l}$ in the absence of $p f h r p 2$ gene suggesting the contribution of $p f h r p 3$ exon2. This finding indicated that the structural homology between epitopes of PfHRP2 and PfHRP3 antigens allows cross-reaction of the monoclonal antibodies of PfHRP2 with PfHRP3 [40], which is in agreement with the previous studies [16, 27]. Indeed, PfHRP2 RDT positive test result with intact $p f h r p 3$ exon 2 might underestimate the true prevalence of pfhrp2 gene deletion in this study.

However, it is yet unclear what causes partial or complete deletion of $p f h r p 2 / 3$ gene in P. falciparum isolates in Assosa zone in Ethiopia. Previous studies have indicated that deletion of $p f h r p 2$ in $\operatorname{Dd} 2$ and $p f h r p 3$ genes in HB3 laboratory strains was resulted from deletion at distinct and unlinked positions on chromosome 8 and 13 , respectively $[10,41,42]$. Thus, selection may act differently on the two gene regions leading to different frequency of deletions. A possible explanation for the presence of a considerable number of deletions of pfhrp $2 / 3$ gene in this region may be the selective pressure of $P$. falciparum isolates with $p f h r p 2$ deletion. This study is located in the Assosa zone, on the border with Sudan, which has a high transmission of malaria. Consequently, intense and routine screening of malaria with a large number of RDTs may pose selective pressure on $P$. falciparum and results in a considerable number of parasites carrying $p f h r p 2 / 3$ gene deletion in this region. Furthermore, in the high transmission setting, polyclonal infection is common. pfhrp $2 / 3$ deleted and non-deleted strains may co-exist within an infected individual and result in positive PfHRP2 RDT [33]. Future study merits expanded samples covering broader geographic regions of Ethiopia and in-depth investigations for the detection of $p f h r p 2 / 3$ deletion in polyclonal infections of $P$. falciparum using a multiplex qPCR and its effect on malaria diagnosis. Further investigations of the PfHRP2 antibodies in the plasma of $P$. falciparum patients infected with pfhrp $2 / 3$ deleted and non-deleted strains will clarify the impact of gene variation on the host immunogenic responses.

\section{Limitations}

This study has certain limitations. Measurement of PfHRP2 antigen in the plasma was not performed. The molecular methods of this study could not show $p f h r p 2 / 3$ gene deletion in polyclonal infections of $P$. falciparum. This study was conducted in a limited geographic area.

\section{Conclusion}

This study confirms the presence of more than $5 \%$ of pfhrp $2 / 3$ gene deletions in P. falciparum isolates in the study area according to the WHO protocol [9]. The high proportion of PfHRP2 RDT false-negative results due to the deletion of $p f h r p 2 / 3$ gene could affect malaria control and elimination efforts in the country. Hence, further country-wide assessment on the magnitude of $p f h r p 2 / 3$ deletions is important before considering alternative malaria diagnostic strategies. 


\section{Supplementary Information}

The online version contains supplementary material available at https://doi. org/10.1186/s12936-021-03629-x.

Additional file 1: Study flow chart for molecular analysis pfhrp2 and pfhrp3 gene.

Additional file 2: Primer sequences, PCR conditions and expected amplicon sizes of Pfhrp2 and Pfhrp3.

Additional file 3: Deletion pattern of Pfhrp2/3 and their respective flanking regions among 218 samples.

Additional file 4: The results of PCR Pfhrp2 exon2, PfHRP2 RDTs, Microscopy with Parasite density $/ \mu$, and qPCR with parasite density/ $\mu$ land $\mathrm{Ct}$ values among P.falciparum positive isolates.

Additional file 5: Pfhrp2 exon2 negatives, pfhrp3 exon2, PfHRP2 RDT and microscopy positive samples

Additional file 6: PfHRP2 RDT and microscopy-based results against PCRbased results of pfhrp2 and pfhrp3 their flanking regions.

\section{Abbreviations}

HRP2: Histidine-Rich Protein 2; PfHRP 2: Plasmodium falciparum HistidineRich Protein 2; RDT: Rapid diagnostic test; SPSS: Statistical Package for Social Sciences; WHO: World Health Organization; DBS: Dried blood spots; PCR: Polymerase chain reaction; $\mathrm{qPCR}$ : Quantitative polymerase chain reaction; $\mathrm{FMOH}$ : Federal Ministry of Health of Ethiopia.

\section{Acknowledgements}

Authors thank Addis Ababa University, Aklilu Lemma Institute of pathobiology for filed data collection support and University of North Carolina at charlotte (Department of Bioinformatics and Genomics, Department of Biological Science) for laboratory and financial support. We would also like to thank Benishangul-Gumuz regional health bureau, Assossa Zonal Health Department, and health centers for provision of the necessary information, facilities and technical supports. We are indebted to data collectors and supervisors for their cooperation during the field work. The study participants are also duly acknowledged for voluntarily supplying the blood sample and responding to the questionnaire.

\section{Authors' contributions}

GA, EL, DJ and LG conceived and designed the study. GA collected the sample. $G A, K B, K L$ and $C C D$ performed laboratory analysis under the direction of $L G$, DJ and EL. All authors reviewed and approved this manuscript.

\section{Funding}

This study was supported in part by Addis Ababa University thematic grant Number RD/LT/505/2016, University of North Carolina at Charlotte (Department of Bioinformatics and Genomics, College of Computing and Informatics, the Bioinformatics Research Center, the Department of Biological Sciences) and the Belk Family, and National institute of health grant number NIH R15 Al138002. The content is exclusively the responsibility of the authors. The funder had no role in study design, data collection and analysis, decision to publish, or preparation of the manuscript.

\section{Availability of data and materials}

The datasets used and/or analysed during in this study are included in this published article and available from the corresponding author on reasonable request.

\section{Ethics approval and consent to participate}

Ethical clearance was obtained from the institutional review board of Aklilu Lemma Institute of Pathobiology, Addis Ababa University (Ref No ALIPB/ IRB006/2017/18). The project was also reviewed and approved by the Institutional Review Board of the University of North Carolina at Charlotte (IRB number 18-0451). Permission was obtained from Benishangul-Gumuz regional Health Bureau. Information about the study, the objective of the study, the possible risks and benefits of the study were explained to the participants or their guardians using the local language. Figure prink blood samples were taken after obtaining written informed consent and assent from parents or guardian's in case of children. Malaria positives were treated by health workers based on national treatment guideline. Confidentiality was maintained throughout the study.

\section{Consent for publication}

This study reports no individual person's data. There is no opposition to its presentation and/or publication. All authors have read and approved the manuscript for publication.

\section{Competing interests}

The authors declare that they have no conflict of interests.

\section{Author details}

${ }^{1}$ Addis Ababa University, Aklilu Lemma Institute of Pathobiology, Addis Ababa, Ethiopia. ${ }^{2}$ Department of Bioinformatics and Genomics, University of North Carolina at Charlotte, Charlotte, NC 28223, USA. ${ }^{3}$ Department of Biological Sciences, Charlotte, University of North Carolina at Charlotte, Charlotte, NC 28223, USA.

Received: 31 July 2020 Accepted: 6 February 2021

Published online: 23 February 2021

\section{References}

1. WHO: World malaria report 2019. Geneva: World Health Organization 2019.

2. FMOH. National Malaria Strategic Plan 2017-2020. Addis Ababa, Ethiopia: 2017

3. WHO. Global Technical Strategy for Malaria 2016-2030. Geneva: World Health Organization; 2016.

4. WHO. Policy brief on malaria diagnostics in low-transmission settings. Geneva: World Health Organization; 2014.

5. EPHI. Malaria laboratory diagnosis external quality assessment scheme guideline. Ethiopian Public Health Institute, Addis Ababa, Ethiopia; 2011.

6. Cheng Q, Gatton ML, Barnwell J, Chiodini P, McCarthy J, Bell D, et al. Plasmodium falciparum parasites lacking histidine-rich protein 2 and 3: a review and recommendations for accurate reporting. Malar J. 2014:13:283.

7. Wellems TE, Howard RJ. Homologous genes encode two distinct histidine-rich proteins in a cloned isolate of Plasmodium falciparum. Proc Natl Acad Sci USA. 1986;83:6065-9.

8. Baker J, Ho M-F, Pelecanos A, Gatton M, Chen N, Abdullah S, et al. Global sequence variation in the histidine-rich proteins 2 and 3 of Plasmodium falciparum: implications for the performance of malaria rapid diagnostic tests. Malar J. 2010;9:129.

9. WHO. Protocol for estimating the prevalence of pfhrp2/pfhrp3 gene deletions among symptomatic falciparum patients with false-negative RDT results. Geneva: World Health Organization; 2018.

10. Gamboa D, Ho M-F, Bendezu J, Torres K, Chiodini PL, Barnwell JW, et al. A large proportion of $P$. falciparum isolates in the Amazon region of Peru lack pfhrp2 and pfhrp3: implications for malaria rapid diagnostic tests. PLoS ONE. 2010;5(1):e8091.

11. Houzé S, Hubert V, Le Pessec G, Le Bras J, Clain J. Combined deletions of pfhrp2 and pfhrp3 genes result in Plasmodium falciparum malaria falsenegative rapid diagnostic test. J Clin Microbiol. 2011:49:2694-6.

12. Kumar N, Pande V, Bhatt R, Shah NK, Mishra N, Srivastava B, et al. Genetic deletion of HRP2 and HRP3 in Indian Plasmodium falciparum population and false negative malaria rapid diagnostic test. Acta Trop. 2013:125:119-21.

13. Wurtz N, Fall B, Bui K, Pascual A, Fall M, Camara C, et al. Pfhrp2 and pfhrp3 polymorphisms in Plasmodium falciparum isolates from Dakar, Senegal: impact on rapid malaria diagnostic tests. Malar J. 2013;12:34.

14. Berhane A, Anderson K, Mihreteab S, Gresty K, Rogier E, Mohamed S, et al. Major threat to malaria control programs by Plasmodium falciparum lacking histidine-rich protein 2. Eritrea Emerg Infect Dis. 2018;24:462.

15. Hamid MA, Awad-Elgeid M, Nasr A. Gene variation and suspected Plasmodium falciparum histidine-rich protein 2 gene deletion and its impact on sensitivity of malaria rapid diagnostic tests in Sudan. BMJ Glob Health. 2017;2:A21. 
16. Beshir KB, Sepúlveda N, Bharmal J, Robinson A, Mwanguzi J, Busula $A O$, et al. Plasmodium falciparum parasites with histidine-rich protein 2 (pfhrp2) and pfhrp3 gene deletions in two endemic regions of Kenya. Sci Rep. 2017;7:1-14718.

17. WHO. Research Malaria Microscopy Standards Working Group. Microscopy for the detection, identification and quantification of malaria parasites on stained thick and thin films. Geneva: World Health Organization; 2015.

18. Baidjoe A, Stone W, Ploemen I, Shagari S, Grignard L, Osoti V, et al. Combined DNA extraction and antibody elution from filter papers for the assessment of malaria transmission intensity in epidemiological studies. Malar J. 2013;12:272.

19. Rougemont M, Van Saanen M, Sahli R, Hinrikson HP, Bille J, Jaton K. Detection of four Plasmodium species in blood from humans by $18 \mathrm{~S}$ rRNA gene subunit-based and species-specific real-time PCR assays. J Clinl Microbiol. 2004;42:5636-43.

20. Parr JB, Anderson O, Juliano JJ, Meshnick SR. Streamlined, PCR-based testing for pfhrp2-and pfhrp3-negative Plasmodium falciparum. Malar J. 2018;17:137.

21. Abdallah JF, Okoth SA, Fontecha GA, Torres REM, Banegas El, Matute ML, et al. Prevalence of pfhrp2 and pfhrp3 gene deletions in Puerto Lempira. Honduras Malar J. 2015;14:19.

22. Wu L, van den Hoogen LL, Slater H, Walker PG, Ghani AC, Drakeley CJ, et al. Comparison of diagnostics for the detection of asymptomatic Plasmodium falciparum infections to inform control and elimination strategies. Nature. 2015;528:S86.

23. Girma S, Cheaveau J, Mohon AN, Marasinghe D, Legese R, Balasingam N, et al. Prevalence and epidemiological characteristics of asymptomatic malaria based on ultrasensitive diagnostics: a cross-sectional study. Clin Infect Dis. 2019;69:1003-10.

24. Gupta H, Matambisso G, Galatas B, Cisteró P, Nhamussua L, Simone W, et al. Molecular surveillance of pfhrp2 and pfhrp3 deletions in Plasmodium falciparum isolates from Mozambique. Malar J. 2017;16:416.

25. Li P, Xing H, Zhao Z, Yang Z, Cao Y, Yan G, Sattabongkot J, et al. Genetic diversity of Plasmodium falciparum histidine-rich protein 2 in the ChinaMyanmar border area. Acta Trop. 2015;152:26-31.

26. Golassa L, Messele A, Amambua-Ngwa A, Swedberg G. High prevalence and extended deletions in Plasmodium falciparum hrp2/3 genomic loci in Ethiopia. PLoS ONE. 2020;15:e0241807.

27. Amoah LA, Abankwa J, Oppong A. Plasmodium falciparum histidine rich protein-2 diversity and the implications for fHRP 2: based malaria rapid diagnostic tests in Ghana. Malar J. 2016;15:101.

28. Kozycki CT, Umulisa N, Rulisa S, Mwikarago El, Musabyimana JP, Habimana JP, et al. False-negative malaria rapid diagnostic tests in Rwanda: impact of Plasmodium falciparum isolates lacking hrp2 and declining malaria transmission. Malar J. 2017;16:123.

29. Shakely D, Elfving K, Aydin-Schmidt B, Msellem MI, Morris U, Omar R, et al. The usefulness of rapid diagnostic tests in the new context of low malaria transmission in Zanzibar. PLoS ONE. 2013;8:e72912.

30. Watson OJ, Verity R, Ghani AC, Garske T, Cunningham J, Tshefu A, et al. Impact of seasonal variations in Plasmodium falciparum malaria transmission on the surveillance of pfhrp2 gene deletions. Elife. 2019;8:e40339.
31. Markwalter CF, Mudenda L, Leelawong M, Kimmel DW, Nourani A, Mbambara S, et al. Evidence for histidine-rich protein 2 immune com plex formation in symptomatic patients in Southern Zambia. Malar J. 2018;17:256.

32. Apinjoh TO, Ouattara A, Titanji VP, Djimde A, Amambua-Ngwa A. Genetic diversity and drug resistance surveillance of Plasmodium falciparum for malaria elimination: is there an ideal tool for resource-limited sub-Saharan Africa? Malar J. 2019;18:217.

33. Watson OJ, Slater HC, Verity R, Parr JB, Mwandagalirwa MK, Tshefu A, et al. Modelling the drivers of the spread of Plasmodium falciparum hrp2 gene deletions in sub-Saharan Africa. Elife. 2017;6:e25008.

34. Sepúlveda N, Phelan J, Diez-Benavente E, Campino S, Clark TG, Hopkins $\mathrm{H}$, et al. Global analysis of Plasmodium falciparum histidine-rich protein-2 (pfhrp2) and pfhrp3 gene deletions using whole-genome sequencing data and meta-analysis. Infect Genet Evol. 2018;62:211-9.

35. Agaba BB, Yeka A, Nsobya S, Arinaitwe E, Nankabirwa J, Opigo J, et al. Systematic review of the status of pfhrp2 and pfhrp3 gene deletion, approaches and methods used for its estimation and reporting in Plasmodium falciparum populations in Africa: review of published studies 2010-2019. Malar J. 2019;18:355.

36. Kreidenweiss A, Trauner F, Rodi M, Koehne E, Held J, Wyndorps L, et al. Monitoring the threatened utility of malaria rapid diagnostic tests by novel high-throughput detection of Plasmodium falciparum hrp2 and hrp3 deletions: a cross-sectional, diagnostic accuracy study. EBioMedicine. 2019;50:14-22.

37. Grignard L, Nolder D, Sepúlveda N, Berhane A, Mihreteab S, Kaaya R, et al. A novel multiplex qPCR Assay for detection of Plasmodium falciparum with histidine-rich protein 2 and 3 (pfhrp2 and pfhrp3) deletions in polyclonal infections. EBioMedicine. 2020;55:102757.

38. WHO. Surveillance template protocol for pfhrp2/pfhrp3 gene deletions. Geneva: World Health Organization; 2020.

39. Ho M-F, Baker J, Lee N, Luchavez J, Ariey F, Nhem S, et al. Circulating antibodies against Plasmodium falciparum histidine-rich proteins 2 interfere with antigen detection by rapid diagnostic tests. Malar J. 2014;13:480.

40. Lee N, Gatton ML, Pelecanos A, Bubb M, Gonzalez I, Bell D, et al. Identification of optimal epitopes for Plasmodium falciparum rapid diagnostic tests that target histidine-rich proteins 2 and 3. J Clin Microbiol. 2012;50:1397-405.

41. Akinyi S, Hayden T, Gamboa D, Torres K, Bendezu J, Abdallah JF, Griffing SM, Quezada WM, Arrospide N, De Oliveira AM. Multiple genetic origins of histidine-rich protein 2 gene deletion in Plasmodium falciparum parasites from Peru. Sci Rep. 2013;3:2797.

42. Kemp D, Thompson J, Walliker D, Corcoran L. Molecular karyotype of Plasmodium falciparum: conserved linkage groups and expendable histidine-rich protein genes. Proc Natl Acad Sci USA. 1987;84:7672-6.

\section{Publisher's Note}

Springer Nature remains neutral with regard to jurisdictional claims in published maps and institutional affiliations.

Ready to submit your research? Choose BMC and benefit from

- fast, convenient online submission

- thorough peer review by experienced researchers in your field

- rapid publication on acceptance

- support for research data, including large and complex data types

- gold Open Access which fosters wider collaboration and increased citations

- maximum visibility for your research: over $100 \mathrm{M}$ website views per year

At BMC, research is always in progress.

Learn more biomedcentral.com/submissions 